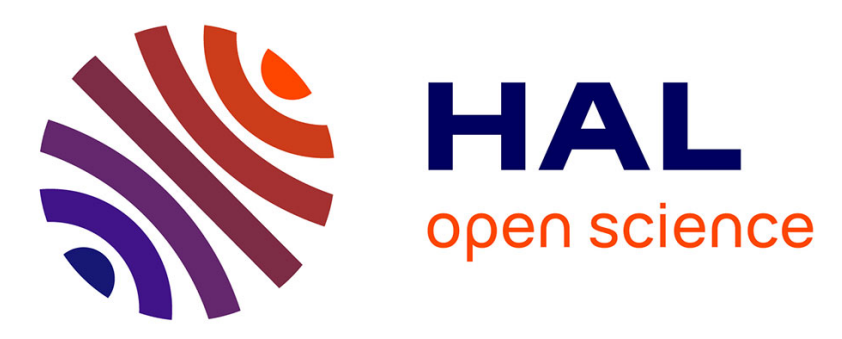

\title{
A photoactive copper iodide phosphine-based coordination polymer
}

Quentin Benito, Nicolas Desboeufs, Alexandre Fargues, Alain Garcia, Florian Massuyeau, Charlotte Martineau-Corcos, Thomas Devic, Sandrine Perruchas

\section{- To cite this version:}

Quentin Benito, Nicolas Desboeufs, Alexandre Fargues, Alain Garcia, Florian Massuyeau, et al.. A photoactive copper iodide phosphine-based coordination polymer. New Journal of Chemistry, 2020, 44 (45), pp.19850-19857. 10.1039/D0NJ04486E . hal-03068397

\section{HAL Id: hal-03068397 \\ https://hal.science/hal-03068397}

Submitted on 15 Dec 2020

HAL is a multi-disciplinary open access archive for the deposit and dissemination of scientific research documents, whether they are published or not. The documents may come from teaching and research institutions in France or abroad, or from public or private research centers.
L'archive ouverte pluridisciplinaire HAL, est destinée au dépôt et à la diffusion de documents scientifiques de niveau recherche, publiés ou non, émanant des établissements d'enseignement et de recherche français ou étrangers, des laboratoires publics ou privés. 


\title{
A photoactive copper iodide phosphine-based
}

\section{coordination polymer}

\author{
Quentin Benito, ${ }^{a}$ Nicolas Desboeufs, ${ }^{a}$ Alexandre Fargues,,${ }^{b}$ Alain Garcia,${ }^{b}$ Florian Massuyeau, ${ }^{c}$ Charlotte \\ Martineau-Corcos,,$^{d, e}$ Thomas Devic, ${ }^{c}$ and Sandrine Perruchas ${ }^{*}, c$
}

a Laboratoire de Physique de la Matière Condensée (PMC), CNRS - Ecole Polytechnique, 91128 Palaiseau Cedex, France.

b Institut de Chimie de la Matière Condensée de Bordeaux (ICMCB) - CNRS, 87 Avenue du Docteur A. Schweitzer, 33608 Pessac Cedex, France.

c Université de Nantes, CNRS, Institut des Matériaux Jean Rouxel, IMN, F-44000 Nantes, France.

Phone: (+33) (0)2 403763 35. E-mail: sandrine.perruchas@cnrs-imn.fr

d MIM, Institut Lavoisier de Versailles (ILV), UMR CNRS 8180, Université de Versailles St-Quentin en Yvelines (UVSQ), 45, avenue des Etats-Unis, 78035 Versailles Cedex, France.

e CNRS, CEMHTI UPR 3079, Université d'Orléans, F-45071 Orléans, France.

\begin{abstract}
A coordination polymer based on the polymetallic $\left[\mathrm{Cu}_{4} \mathrm{I}_{4}\right]$ center was synthesized by coordination with a phenyl-based-diphosphine ligand. The structure of this solid formulated $\left[\mathrm{Cu}_{4} \mathrm{I}_{4}\left(\mathrm{Ph}_{2} \mathrm{P}\left(\mathrm{C}_{6} \mathrm{H}_{4}\right)_{2} \mathrm{PPh}_{2}\right)_{2}\right]_{\mathrm{n}}$, although crystalline, could not be completely resolved by powder X Ray diffraction. Nevertheless, combining different characterization techniques and in particular the ${ }^{63} \mathrm{Cu}$ and ${ }^{31} \mathrm{P}$ solid-state NMR analyses, permit to get insights into the polymeric structure. This coordination polymer appears to be of high dimensionally with possible interpenetrated networks, resulting in low porosity. Photoluminescence characterization revealed original luminescence thermochromic properties ascribed to the photoactive $\left[\mathrm{Cu}_{4} \mathrm{I}_{4}\left(\mathrm{PPh}_{2}-\right)_{4}\right]$ cluster unit.
\end{abstract}

Keywords. Copper iodide cluster, diphosphine ligand, coordination polymer, luminescence thermochromism. 


\section{Introduction.}

Luminescent coordination polymers are attracting attention due to their potential applications for chemical sensing and detection. ${ }^{1,2,3,4,5}$ The most commonly studied metallic ions are $\mathrm{Zn}$ (II) and $\mathrm{Cd}$ (II) and in those cases, the luminescence properties arise from the ligands having in general conjugated organic backbone.,7 Lanthanide-based coordination polymers are also widely studied but the intrinsic photophysical properties of the $\mathrm{Ln}(\mathrm{III})$ ions, limit their stimuli-responsive properties. ${ }^{8}$

Copper(I) iodide complexes exhibit a wide range of optical properties and constitute attractive components for designing original emissive materials. ${ }^{9}, 10,11,12,13,14,15,16$ In particular, molecular copper iodide clusters present extremely rich photoluminescent stimuli-responsive properties. ${ }^{17,18,19,20,21}$ Amongst those clusters, the [Cu $\left.{ }^{2} \mathrm{I}_{4} \mathrm{~L}_{4}\right]$ ( $\mathrm{L}=$ organic ligand) one of cubane geometry stands out. This cluster is built on a $\mathrm{Cu}_{4}$ tetrahedron embedded into a larger $\mathrm{I}_{4}$ one, and the four organic ligands are coordinated to the $\mathrm{Cu}$ atoms (Figure 1). ${ }^{22}\left[\mathrm{Cu}_{4} \mathrm{I}_{4} \mathrm{~L}_{4}\right]$ clusters present a large panel of photoluminescent properties with stimuli-responsive features such as luminescence thermochromism, ${ }^{23,24}$ mechanochromism, ${ }^{25}$ rigidochromism, ${ }^{26}$ or vapo/solvatochromism. ${ }^{27}$ Combining multistimuli-responsive properties is particularly appealing to access original multifunctional materials toward sensory applications. Promising applicative perspectives have been already reported with the successful use of $\left[\mathrm{Cu}_{4} \mathrm{I}_{4} \mathrm{~L}_{4}\right]$ clusters as ink ${ }^{28}$ and as phosphors ${ }^{29}$ or emitters ${ }^{30}$ in lighting devices.

The study of $\left[\mathrm{Cu}_{4} \mathrm{I}_{4} \mathrm{~L}_{4}\right]$ clusters for the synthesis of coordination polymers is thus especially appealing to obtain original photoactive materials. Moreover, the particular geometry of this polymetallic node is expected to lead to coordination network of high dimensionality. Indeed, coordination to the $\mathrm{Cu}$ atoms of the $\mathrm{Cu}_{4}$ tetrahedron should lead to a layout of the ligand in a tetrahedral fashion. The $\left[\mathrm{Cu}_{4} \mathrm{I}_{4}\right]$ metallic center can be thus viewed as an expanded version of a four-fold coordinated single metallic center. These interesting structural and photophysical characteristics motivated investigations and several coordination polymers incorporating the $\left[\mathrm{Cu}_{4} \mathrm{I}_{4}\right]$ metallic center have been reported. Most of the reported coordination polymers were synthesized with nitrogen $^{29,31}$ and sulfur-based ${ }^{32}$ ligands having flexible structure while the study of rigid ligands is less documented. ${ }^{33,34,35,36,37}$ The use of rigid ligands is well known to lead to network of high dimensionality with potential porous character. ${ }^{38}$ Bidentate rigid phosphine ligands are commonly employed in coordination chemistry but their use for designing coordination polymers is rarely encountered ${ }^{39}$ and to our knowledge, not reported with copper iodide derivatives. Note however that cyclodiphosphazane derivatives were successfully employed to generate $\left[\mathrm{Cu}_{4} \mathrm{I}_{4}\right]$-based coordination polymers but their optical properties were not investigated. ${ }^{40}$
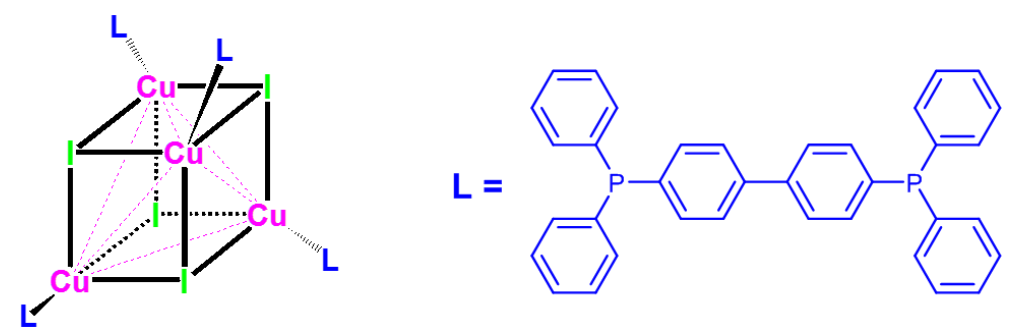

Figure 1. Molecular structure of the $\left[\mathrm{Cu}_{4} \mathrm{I}_{4}\right]$ cubane cluster core and the studied diphosphine $\mathrm{Ph}_{2} \mathrm{P}\left(\mathrm{C}_{6} \mathrm{H}_{4}\right)_{2} \mathrm{PPh}_{2}$ ligand.

Here, we report on the synthesis, structural and optical characterizations of a coordination polymer based on the $\left[\mathrm{Cu}_{4} \mathrm{I}_{4}\right]$ cluster core connected by rigid diphosphine ligands (Figure 1), formulated $\left[\mathrm{Cu}_{4} \mathrm{I}_{4}\left(\mathrm{Ph}_{2} \mathrm{P}\left(\mathrm{C}_{6} \mathrm{H}_{4}\right)_{2} \mathrm{PPh}_{2}\right)_{2}\right]_{\mathrm{n}}$ (1). Although straightforward structural characterization by SCXRD analysis was not possible, combination of PXRD and solid-state NMR analysis permit to get insights into the nature of the 
polymeric structure. The photophysical characterizations reveal a contrasted luminescence thermochromism with dual emission interplay ascribed to the photoactive $\left[\mathrm{Cu}_{4} \mathrm{I}_{4}\left(\mathrm{PPh}_{2}-\right)_{4}\right]$ cluster unit.

\section{Experimental Section.}

\section{Synthesis.}

The solvents, tetrabutylammonium iodide (TBAI) and copper(I) iodide (CuI) were purchased from Aldrich and used as received. The 4,4'-bis(diphenylphosphino)biphenyl phosphine ligand $\left(\mathrm{Ph}_{2} \mathrm{P}_{(}\left(\mathrm{C}_{6} \mathrm{H}_{4}\right)_{2} \mathrm{PPh}_{2}\right)$ was synthesized according to literature procedure ${ }^{41}$ by lithiation of $4,4^{\prime}$-dibromodiphenyl followed by reaction with chlorodiphenylphosphine.

$\left[\mathrm{Cu}_{4} \mathrm{I}_{4}\left(\mathrm{Ph}_{2} \mathrm{P}\left(\mathrm{C}_{6} \mathrm{H}_{4}\right)_{2} \mathrm{PPh}_{2}\right)_{2}\right]_{\mathrm{n}}(\mathbf{1})$. To a suspension of $\mathrm{CuI}(270 \mathrm{mg}, 1.4 \mathrm{mmol})$ in $5 \mathrm{~mL}$ of acetonitrile was added TBAI (530 mg, $1.4 \mathrm{mmol})$ and $\mathrm{Ph}_{2} \mathrm{P}\left(\mathrm{C}_{6} \mathrm{H}_{4}\right)_{2} \mathrm{PPh}_{2}(250 \mathrm{mg}, 0.48 \mathrm{mmol})$. The reaction mixture was placed in a Parr autoclave and heated at $120{ }^{\circ} \mathrm{C}$ for $63 \mathrm{~h}$. The resulting yellowish powder was filtrated and rinsed with acetonitrile. Yield $=40 \%$ based on $\mathrm{CuI}\left(1.01 \mathrm{~g}, 0.56 \mathrm{mmol}\right.$, for $\left[\mathrm{Cu}_{4} \mathrm{I}_{4}\left(\mathrm{Ph}_{2} \mathrm{P}\left(\mathrm{C}_{6} \mathrm{H}_{4}\right)_{2} \mathrm{PPh}_{2}\right)_{2}\right] \mathrm{M}=1806$ g.mol $\left.{ }^{-1}\right)$.

Anal. Calcd (\% wt.) for $\mathrm{C}_{72} \mathrm{H}_{56} \mathrm{P}_{4} \mathrm{Cu}_{4} \mathrm{I}_{4}$ : C, 47.86; H, 3.12; Found: C, 47.83; H, 3.27.

\section{Characterizations.}

Elemental analyses $(\mathrm{C}, \mathrm{H}, \mathrm{N})$ were performed by the Service de microanalyse de l'ICSN - CNRS Gif-sur-Yvette, France.

The solid state static ${ }^{65} \mathrm{Cu}$ NMR spectra of $\mathbf{1}$ and 2 were recorded on a Bruker Avance $500 \mathrm{MHz}$ spectrometer $\left(\mathrm{B}_{0}=11.7 \mathrm{~T}\right)$ using a quadrupolar echo in static condition, with an inter-pulse delay of $100 \mu \mathrm{s}$. The recycle delay was $1 \mathrm{~s}$. Total acquisition time is 3 days per sample. The spectra are referenced to $\mathrm{CuI}$ at $0 \mathrm{ppm}$. The samples were packed in $4 \mathrm{~mm}$ outer diameter rotor. The ${ }^{1} \mathrm{H}$ MAS, ${ }^{1} \mathrm{H}^{31} \mathrm{P}$ cross-polarization $(\mathrm{CP})$ magic-angle spinning (MAS) and ${ }^{1} \mathrm{H}-{ }^{13} \mathrm{C}$ CPMAS NMR spectra of 1, 2 and the ligand were recorded at MAS frequency of 10-12.5 kHz. For both $\mathrm{CP}$ experiments, the contact time was set to $3 \mathrm{~ms}$ and the recycling delay to $10 \mathrm{~s}$. ${ }^{1} \mathrm{H}$ SPINAL-64 decoupling is applied during the signal acquisition. The ${ }^{1} \mathrm{H}$ and ${ }^{13} \mathrm{C}$ chemical shifts were referenced to TMS at $0 \mathrm{ppm}$, the ${ }^{31} \mathrm{P}$ chemical shifts were referenced to a solution of $\mathrm{H}_{3} \mathrm{PO}_{4}$ at $0 \mathrm{ppm}$. All spectra were analyzed using the Dmfit software. ${ }^{42}$

Luminescence spectra were recorded on a SPEX Fluorolog FL 212 spectrofluorimeter (Horiba Jobin Yvon). The excitation source is a 450 Watt xenon lamp, excitation spectra were corrected for the variation of the incident lamp flux, as well as emission spectra for the transmission of the monochromator and the response of the photomultiplier (Peltier cooled Hamamatsu R928P photomultiplier). Low temperature measurements were recorded with a liquid helium circulation cryostat SMC TBT Air Liquid model C102084. The absolute internal quantum yields $(\Phi)$ were measured by using the Jobin Yvon integrating sphere. The error of the measured values has been evaluated to $10 \%$. Emission lifetimes $(\tau)$ were recorded with a time-resolved photoluminescence setup consisting of a frequency-tripled regenerative amplified femtosecond Ti:sapphire laser system from Spectra Physics to obtain $\lambda_{\mathrm{ex}}=266 \mathrm{~nm}$ and a C7700 streak camera from Hamamatsu coupled to an SP2300 imaging Acton spectrograph for the luminescence detection. Data were analyzed by exponential curve fitting using Origin software.

The high resolution powder X-ray diffraction (PXRD) diagram was measured at room temperature on a Bruker D8 Advance diffractometer with a Debye-Scherrer geometry, in the $2 \theta$ range $7-100^{\circ}$. The D8 system is equipped with a $\mathrm{Ge}(111)$ monochromator producing $\mathrm{Cu} \mathrm{K \alpha} 1$ radiation $(\lambda=1.540598 \AA)$ and a LynxEye detector. The 
XRD pattern was indexed by means of the software DICVOL, ${ }^{43}$ with an absolute error in peak positions of 0.03 ${ }^{\circ}(2 \theta)$. The subsequent Le Bail structure-independent fit was performed using FullProf software ${ }^{44}$ integrated in the WinPlotr suite. ${ }^{45}$

FTIR (Fourier Transform Infra-Red) spectra was recorded on powder with a Bruker alpha spectrometer in ATR mode.

TGA (Thermogravimetric Analysis) was performed on a Mettler Toledo TGA/DSC 1, STAR®System apparatus under pure $\mathrm{O}_{2}$, at a heating rate of $5^{\circ} \mathrm{C} \cdot \mathrm{min}^{-1}$ up to $600^{\circ} \mathrm{C}$.

$\mathrm{N}_{2}$ sorption measurement was performed at $77 \mathrm{~K}$ on BEL Japan Belsorp Mini apparatus. Prior to measurement, the solid was heated at $373 \mathrm{~K}$ under primary vacuum for one day.

$\mathrm{CO}_{2}$ sorption measurement was carried out at $298 \mathrm{~K}$ up to 20 bars using a gravimetric IGA Hiden Isochema apparatus. The sample was outgassed under a secondary vacuum $\left(10^{-6} \mathrm{~Pa}\right)$ at $373 \mathrm{~K}$ for one day prior to the measurement.

\section{Results and Discussions.}

$\left[\mathrm{Cu}_{4} \mathrm{I}_{4}\left(\mathrm{Ph}_{2} \mathrm{P}\left(\mathrm{C}_{6} \mathrm{H}_{4}\right)_{2} \mathrm{PPh}_{2}\right)_{2}\right]_{\mathrm{n}}(\mathbf{1})$ was synthesized by reacting $\mathrm{CuI}$ and the diphosphine ligand in acetonitrile under solvothermal conditions. The addition of TBAI to the reaction medium appeared to enhance the reaction yield probably due to an increase of $\mathrm{CuI}$ solubility in the reacting medium. The compound was obtained as a yellowish powder. Different synthesis conditions were explored by varying the reactants ratios and concentrations, solvents, temperature, but all attempts to obtain single crystal were unsuccessful. Instead, no or lower reaction yields were obtained. TGA indicated no mass loss up to $330{ }^{\circ} \mathrm{C}$ that is in agreement with the absence of any entrapped solvent (Figure S1).

The $\mathrm{Ph}_{2} \mathrm{P}\left(\mathrm{C}_{6} \mathrm{H}_{4}\right)_{2} \mathrm{PPh}_{2}$ ligand can be viewed as two connected $\mathrm{PPh}_{3}$ units (Figure 1). If we consider that each bidentate ligand is coordinated to $\left[\mathrm{Cu}_{4} \mathrm{I}_{4}\right]$ centers, then the formed coordination polymer is the result of the fusion of $\left[\mathrm{Cu}_{4} \mathrm{I}_{4}\left(\mathrm{PPh}_{3}\right)_{4}\right]$ units. The molecular cluster $\left[\mathrm{Cu}_{4} \mathrm{I}_{4}\left(\mathrm{PPh}_{3}\right)_{4}\right](2)$ is the prototypical member in the family of cubane copper iodides coordinated by phosphine ligands and has been well characterized. ${ }^{24,46,47,48}$ Comparing data of 1 and 2 appears thus relevant to get insights into the structure and to rationalize the photophysical properties of the coordination polymer 1.

In order to analyze the local structure of $\mathbf{1}$, solid-state NMR experiments were conducted. The different nuclei, ${ }^{1} \mathrm{H},{ }^{13} \mathrm{C},{ }^{31} \mathrm{P}$ and ${ }^{65} \mathrm{Cu}$ were analyzed. The last two are very informative regarding the geometrical characteristics of copper iodide complexes. The ${ }^{31} \mathrm{P}$ CPMAS NMR spectrum of $\mathbf{1}$ presents a broad signal centered at $-25 \mathrm{ppm}$, as shown in Figure 2. The spectrum of the molecular cluster $\left[\mathrm{Cu}_{4} \mathrm{I}_{4}\left(\mathrm{PPh}_{3}\right)_{4}\right](2)$ is also reported for comparison. ${ }^{49}$ The latter displays well resolved peaks but with a similar pattern (envelop) and a close chemical shift value compared with 1 . The multiple peaks observed in 2 result from the one-bond $J$-couplings between the ${ }^{31} \mathrm{P}$ and the two copper ${ }^{65} \mathrm{Cu}$ and ${ }^{63} \mathrm{Cu}$ isotopes (30.8 and $69.2 \%$ of natural abundance, respectively) both having a nuclear spin value of 3/2. In that case, each independent phosphorus atom (two in 2) gives rise to two quartets which overlap in $\mathbf{2}$. The broad feature of the spectrum of $\mathbf{1}$ indicates static or dynamical disorder in the structure. This latter could be attributed to the flexibility of the phenyl groups $\left(\mathrm{PPh}_{2}\right)$ having free rotation around the P-C bonds. Comparable chemical shifts in $\mathbf{1}$ and 2, confirms that the phosphorus atoms are all coordinated to copper atoms. This is further validated by the lack of signal of uncoordinated phosphorus as that observed for the free ligand with a single peak at $-10 \mathrm{ppm}$. Note that little phosphine oxide is detected around 
$+25 \mathrm{ppm}$. This small amount can be attributed to oxidation of the compound's surface during the measurement, since it is not detected in other analysis (elemental analysis).

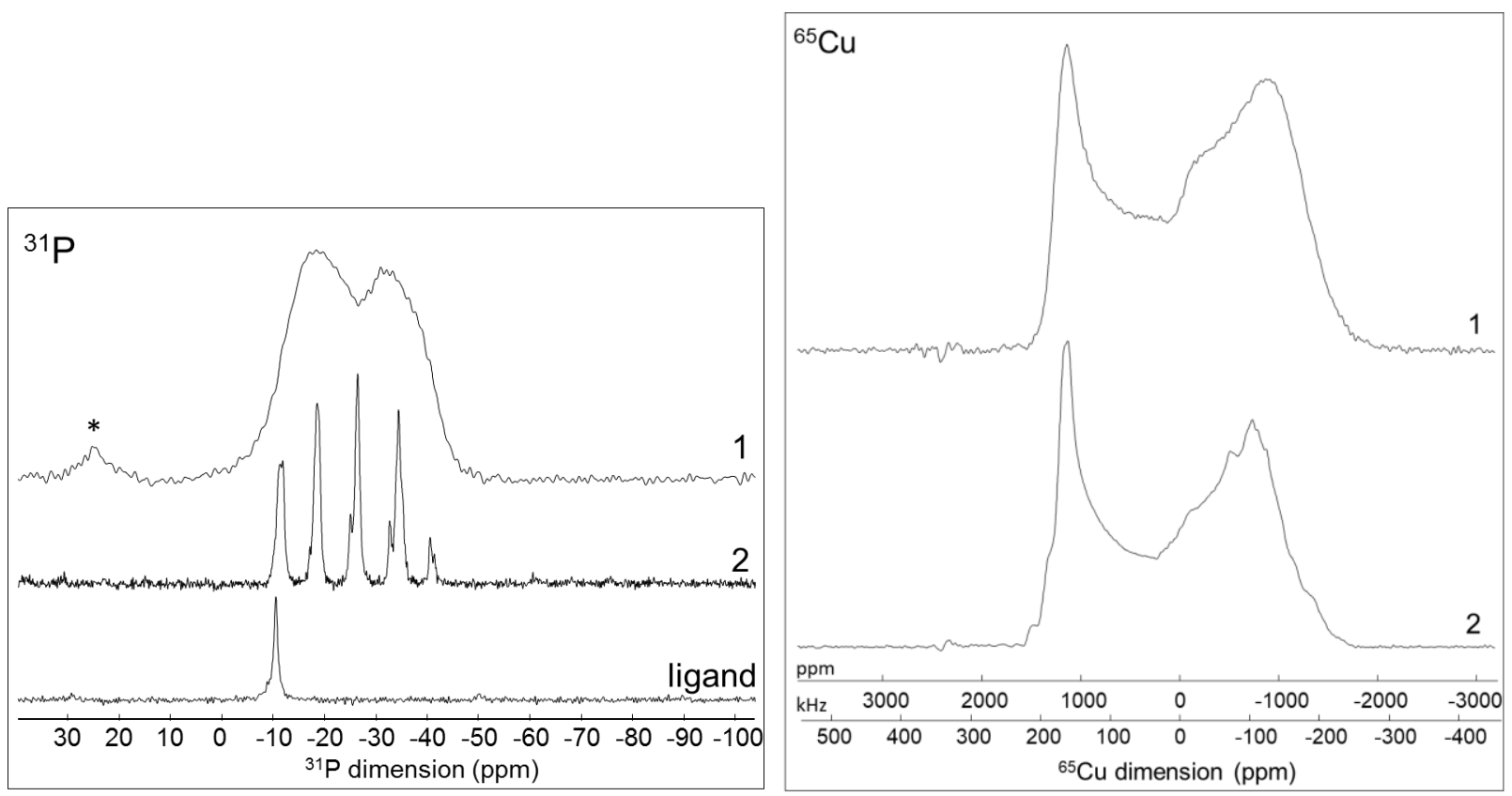

Figure 2. Solid-state ${ }^{31} \mathrm{P}$ CPMAS NMR spectra of $\mathbf{1}, 2$ and the ligand $\mathrm{Ph}_{2} \mathrm{P}\left(\mathrm{C}_{6} \mathrm{H}_{4}\right)_{2} \mathrm{PPh}_{2}$ with * denoting a small amount of phosphine oxide, and ${ }^{65} \mathrm{Cu}$ static WURST-QCPMG NMR spectra of $\mathbf{1}$ and $\mathbf{2}$.

The ${ }^{65} \mathrm{Cu}$ static NMR spectrum of $\mathbf{1}$ is shown in Figure 2 and presents a broad feature extending over more than $400 \mathrm{kHz}$ due to the large quadrupolar moment of the ${ }^{65} \mathrm{Cu}$ nucleus. The individual components are strongly overlapped, even at high magnetic field $(11 \mathrm{~T})$, preventing deconvolution. Similarity with the spectra of $\left[\mathrm{Cu}_{4} \mathrm{I}_{4}\left(\mathrm{PPh}_{3}\right)_{4}\right](2)$ is striking, the span and shape of the patterns are almost identical. This signature is typical of copper atoms in $\mathrm{PCuI}_{3}$ four-fold coordination geometry ${ }^{50}$ that is clearly distinct from the three-coordinated $\mathrm{PCuI}_{2}{ }^{51}$ and the four-coordinate $\mathrm{P}_{2} \mathrm{CuI}_{2}$ and $\mathrm{CuI}_{4}$, copper environments. ${ }^{49}$ Therefore, this result confirms without doubt the presence of $\left[\mathrm{Cu}_{4} \mathrm{I}_{4}\right]$ cluster core of cubane geometry in $\mathbf{1}$ for which the $\mathrm{Cu}$ atoms are coordinated by the phosphine ligand. The resonance in the ${ }^{65} \mathrm{Cu}$ NMR spectrum of 1 is slightly broadened compared with those of 2 indicating small local disorder as already detected in the ${ }^{31} \mathrm{P}$ NMR analysis. Such disorder has been already observed in coordination polymers presenting some flexibility of the inorganic or organic part. ${ }^{52}$ 

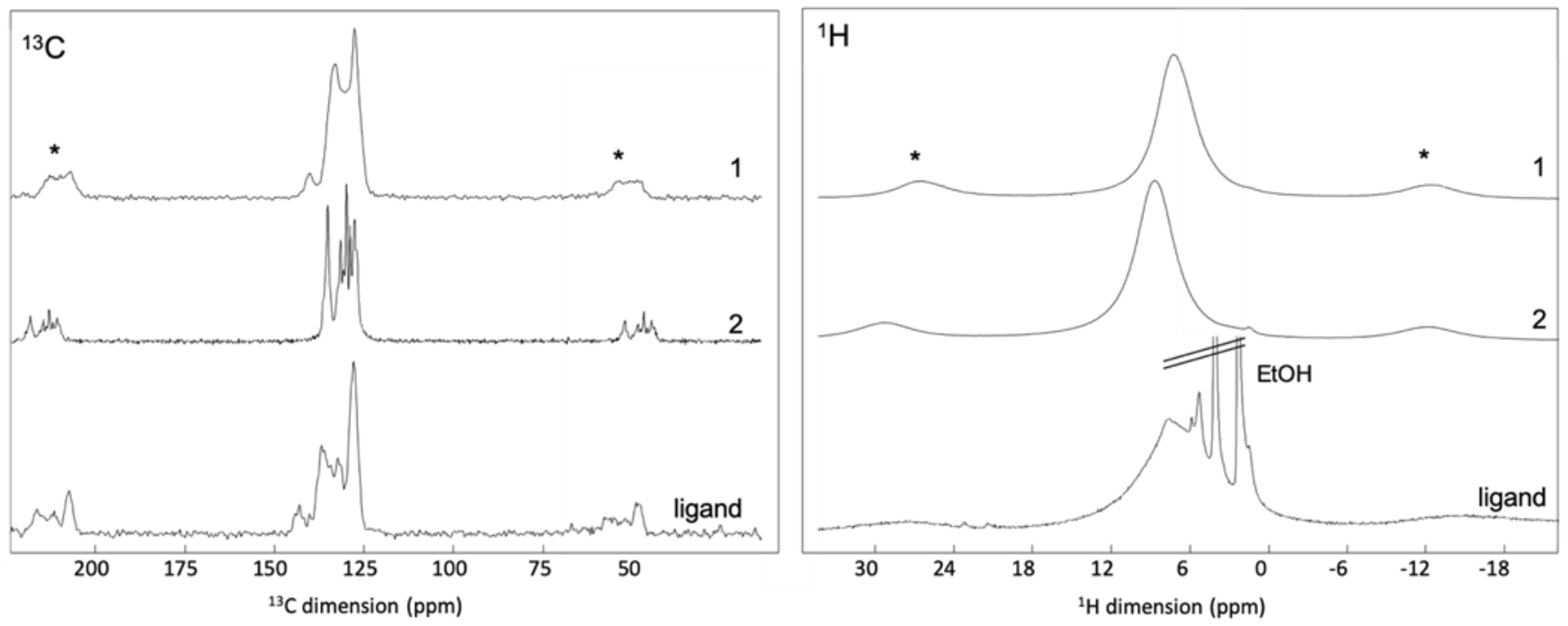

Figure 3. Solid-state NMR ${ }^{13} \mathrm{C}$ and ${ }^{1} \mathrm{H}$ MAS spectra of $\mathbf{1}$ and $\mathbf{2}, *$ denotes spinning side bands.

The ${ }^{13} \mathrm{C}$ and ${ }^{1} \mathrm{H}$ NMR spectra of $\mathbf{1}$ are reported in Figure 3. The ${ }^{13} \mathrm{C}$ NMR spectrum is typical of phenyl-based derivatives with signal of aromatic carbons around $-130 \mathrm{ppm}$. The ${ }^{1} \mathrm{H}$ NMR spectrum presents a broad signal centered at $-9 \mathrm{ppm}$ in accordance with phenyl and phenylene groups. As expected, both ${ }^{13} \mathrm{C}$ and ${ }^{1} \mathrm{H}$ NMR spectra are comparable to those of the free ligand and of 2 . No signal of other carbon- and hydrogen-based compounds is detected in agreement with no entrapped solvent in the structure of $\mathbf{1}$.

From the NMR analysis, it is deduced that each phosphorus atom of the ligands is coordinated to one copper atom of $\left[\mathrm{Cu}_{4} \mathrm{I}_{4}\right]$ centers so the expected coordination polymer can be represented as illustrated in Figure 4 and is formulated $\left[\mathrm{Cu}_{4} \mathrm{I}_{4}\left(\mathrm{Ph}_{2} \mathrm{P}\left(\mathrm{C}_{6} \mathrm{H}_{4}\right)_{2} \mathrm{PPh}_{2}\right)_{2}\right]_{\mathrm{n}}$. As highlighted in Figure 4, 1 can be viewed as connected $\left[\mathrm{Cu}_{4} \mathrm{I}_{4}\left(\mathrm{PPh}_{3}\right)_{4}\right]$ units through one phenyl group of the ligands ( $\mathrm{H}$ atoms in para position suppressed), as already mentioned. The $\left[\mathrm{Cu}_{4} \mathrm{I}_{4}\left(\mathrm{Ph}_{2} \mathrm{P}\left(\mathrm{C}_{6} \mathrm{H}_{4}\right)_{2} \mathrm{PPh}_{2}\right)_{2}\right]_{\mathrm{n}}$ formula is confirmed by elemental analysis pointing out the 1:2 ligand:Cu stoichiometry. This analysis also confirms the absence of solvent in the structure. Only one other example of coordination complex of copper iodide with the studied ligand has been reported which is formulated $\left[(\mathrm{CuI})_{2}\left(\mathrm{Ph}_{2} \mathrm{P}\left(\mathrm{C}_{6} \mathrm{H}_{4}\right)_{2} \mathrm{PPh}_{2}\right)_{2}\right]{ }^{53}$ This complex consists in a molecular mesocate involving mononuclear CuI units with a 1:1 ligand:Cu stoichiometry. 


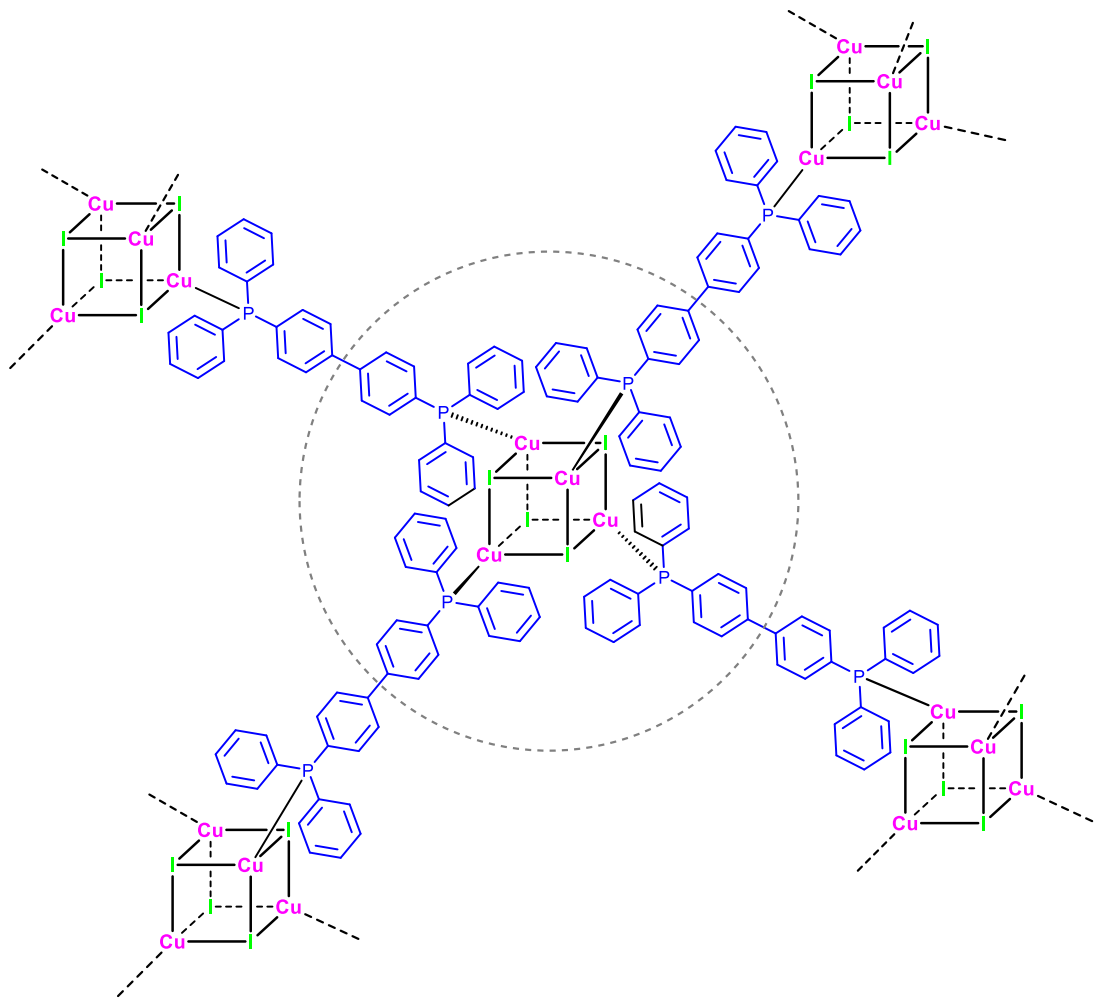

Figure 4. Schematic drawing of the polymeric structure of 1 . Structural analogy with connected $\left[\mathrm{Cu}_{4} \mathrm{I}_{4}\left(\mathrm{PPh}_{3}\right)_{4}\right]$ clusters is highlighted by the circle in dotted line.

The FTIR spectra were recorded for 1, 2 and the ligand in the two 45-650 and 400-4000 $\mathrm{cm}^{-1}$ ranges (Figure 5 and SI). The low frequencies region was analyzed because the vibrational bands of the $\left[\mathrm{Cu}_{4} \mathrm{I}_{4}\right]$ cluster core lie in this range. ${ }^{54,55,56}$ Below $400 \mathrm{~cm}^{-1}$ (Figure S2), all vibrations of 1 correspond to the $\mathrm{PPh}_{2}\left(\mathrm{C}_{6} \mathrm{H}_{4}\right)_{2} \mathrm{PPh}_{2}$ ligand. In the $45-650 \mathrm{~cm}^{-1}$ range, 1 presents two bands at $95 \mathrm{~cm}^{-1}$ and $132 \mathrm{~cm}^{-1}$. These two bands also displayed by 2 are characteristic of molecular $\left[\mathrm{Cu}_{4} \mathrm{I}_{4} \mathrm{~L}_{4}\right]$ clusters of cubane structure and correspond to $\mathrm{Cu}-\mathrm{I}$ bond vibrations. ${ }^{54,55,56}$ The band observed at $434 \mathrm{~cm}^{-1}$ only presents in the spectra of $\mathbf{1}$ and the ligand can be attributed to C-H vibration of the phosphine ligand. The broad band centered at $511 \mathrm{~cm}^{-1}$ can be attributed to vibrations of the phenyl groups. The band at $618 \mathrm{~cm}^{-1}$ in the spectra of 1 and 2 may be attributed to $\mathrm{Cu}-\mathrm{P}$ bond vibration. The IR analysis agrees with the ${ }^{31} \mathrm{P}$ solid-state NMR study and confirms the $\left[\mathrm{Cu}_{4} \mathrm{I}_{4}\right]$ cluster core coordinated by $\mathrm{PPh}_{2}\left(\mathrm{C}_{6} \mathrm{H}_{4}\right)_{2} \mathrm{PPh}_{2}$ ligands in the structure of $\mathbf{1}$. 


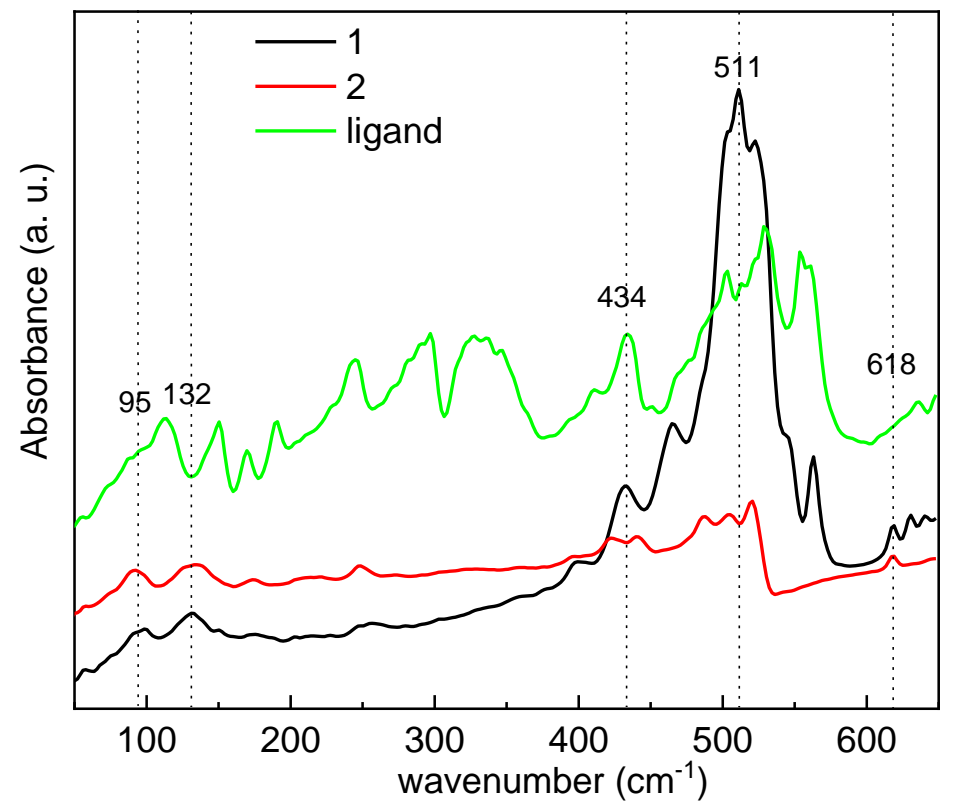

Figure 5. FTIR spectra of 1, 2 and the ligand.

The PXRD diagram of $\mathbf{1}$ presents well defined diffraction peaks attesting the crystallinity of the coordination polymer (Figure 6). Indexation of the diagram (DicVol FullProf) gave as the best result a cubic cell of parameter $a=14.9894(7) \AA\left(V=3367.9(3) \AA^{3}\right)$ while extinctions suggest $I 23, I 213, I m-3, I 432, I-43 m, I m-3 m$ as possible space groups.

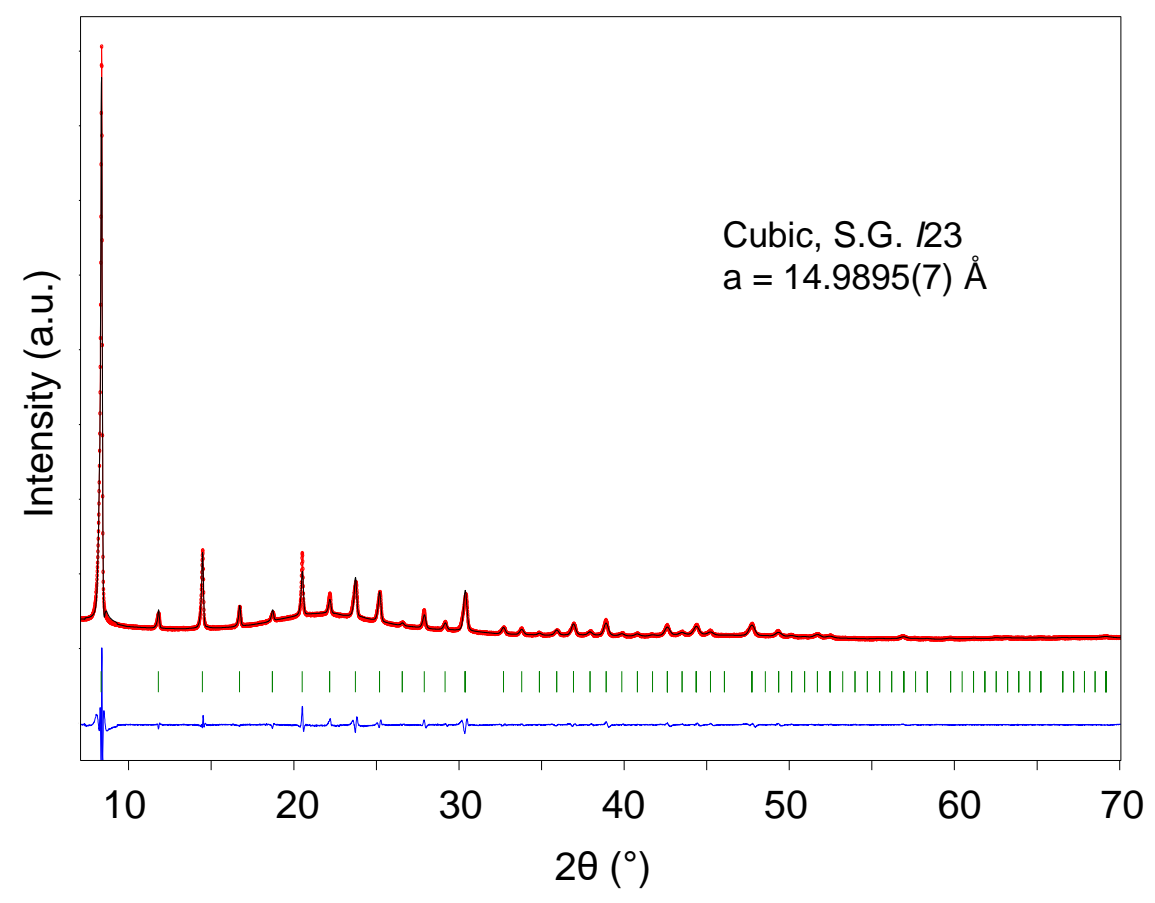

Figure 6. PXRD diagram and pattern matching of $\mathbf{1}$.

As mentioned above, the NMR study and chemical analyses indicate a stoichiometry of two ligands per $\left[\mathrm{Cu}_{4} \mathrm{I}_{4}\right]$ unit. Nitrogen and carbon dioxide sorption experiments performed at 77 and $298 \mathrm{~K}$ respectively, revealed the non-porous character of 1 (ESI, Figures S3 and S4). One can thus expect an average volume par atom of $c a .20$ $\AA^{3}$ in this structure, as found in dense compounds of similar composition (20.9 and $18.9 \AA^{3}$ per atom in 
$\left[\mathrm{Cu}_{4} \mathrm{I}_{4}\left(\mathrm{PPh}_{3}\right)_{4}\right]^{46}$ and $\left[(\mathrm{CuI})_{2}\left(\mathrm{Ph}_{2} \mathrm{P}\left(\mathrm{C}_{6} \mathrm{H}_{4}\right)_{2} \mathrm{PPh}_{2}\right)_{2}\right],{ }^{53}$ respectively). Considering the determined cell volume, this corresponds to the formula $\left[\mathrm{Cu}_{4} \mathrm{I}_{4}\left(\mathrm{Ph}_{2} \mathrm{P}\left(\mathrm{C}_{6} \mathrm{H}_{4}\right)_{2} \mathrm{PPh}_{2}\right)_{2}\right]$ in the unit-cell. Preliminary attempts to solve the structure permits to localize the $\left[\mathrm{Cu}_{4} \mathrm{I}_{4}\right]$ cluster core but the organic part was not resolved because of a symmetry conflict. Indeed, the 3-fold axis presents in the cubic cell passing through the long diagonal of the $\left[\mathrm{Cu}_{4} \mathrm{I}_{4}\right]$ center is not compatible with the phosphine ligand $\left(\mathrm{Ph}_{2} \mathrm{P}\left(\mathrm{C}_{6} \mathrm{H}_{4}\right)_{2} \mathrm{PPh}_{2}\right)$, as the ligand itself cannot sustain a 3-fold axis. Considering the content of the unit-cell, the heteroatoms $(\mathrm{Cu}, \mathrm{I}, \mathrm{P})$ should lie on a crystallographic site of multiplicity lower or equal to 8 . Nevertheless, in the possible space groups, these sites are either located on a 3 fold axis or incompatible with the geometry of the $\left[\mathrm{Cu}_{4} \mathrm{I}_{4} \mathrm{P}_{4}\right]$ unit, which was unambiguously identified by solidsate NMR and luminescence studies (see below). Hence, the unit cell parameters and/or the symmetry are wrong, and either additional diffraction peaks or peaks splitting must be present. Nevertheless, none of these features were detected on PXRD data. This probably arises from the moderate crystallinity of $\mathbf{1}$, which gives rise to peak broadening preventing the detection of peak splitting, and hence the definitive indexation of the PXRD pattern.

The 'primary' structure of the studied coordination polymer $\left[\mathrm{Cu}_{4} \mathrm{I}_{4}\left(\mathrm{Ph}_{2} \mathrm{P}\left(\mathrm{C}_{6} \mathrm{H}_{4}\right)_{2} \mathrm{PPh}_{2}\right)_{2}\right]_{\mathrm{n}}(\mathbf{1})$ consisting of $\left[\mathrm{Cu}_{4} \mathrm{I}_{4}\right]$ centers coordinated by the rigid diphosphine ligand $\left(\mathrm{Ph}_{2} \mathrm{P}\left(\mathrm{C}_{6} \mathrm{H}_{4}\right)_{2} \mathrm{PPh}_{2}\right)$ is ascertained by the different characterizations results. However, the global spatial layout of this polymeric structure could not be elucidated by X-Ray diffraction analysis. Formation of low dimensionally compounds (1-D) is unlikely due to the steric hindrance of the eight phenyl groups that should favor the isotropic repartition of the ligands around the [ $\left.\mathrm{Cu}_{4} \mathrm{I}_{4}\right]$ cluster core. Instead, the tetrahedral coordination geometry of the polymetallic center preserved by the rigid ligand, should promote the formation of either 2-D or 3-D networks. The non-porous character of 1 could be related to the bulkiness of the ligand and/or networks interpenetration.

Regarding the photophysical properties, the yellowish powder of $\left[\mathrm{Cu}_{4} \mathrm{I}_{4}\left(\mathrm{Ph}_{2} \mathrm{P}\left(\mathrm{C}_{6} \mathrm{H}_{4}\right)_{2} \mathrm{PPh}_{2}\right)_{2}\right]_{\mathrm{n}}(\mathbf{1})$ emits in the yellow range under UV illumination, at room temperature (Figure 7). When cooled to $77 \mathrm{~K}$, the emission becomes bright green and more intense. With this contrasted emission color change, which is completely reversible, 1 displays thermochromic luminescence properties.

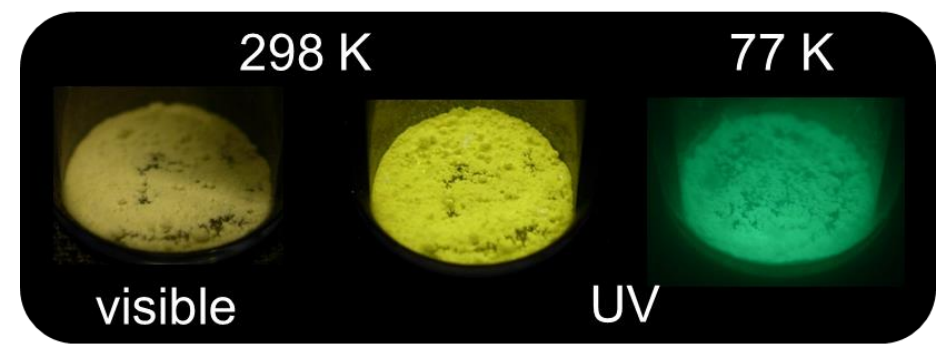

Figure 7. Photographs of powder of 1 under ambient light and UV irradiation ( $365 \mathrm{~nm}$ UV lamp) at room temperature (298 $\mathrm{K})$ and in liquid nitrogen $(77 \mathrm{~K})$.

Temperature-dependent solid-state emission and excitation spectra were recorded from 20 to $290 \mathrm{~K}$ and are shown in Figure 8. At $290 \mathrm{~K}\left(\lambda_{\mathrm{ex}}=300 \mathrm{~nm}\right)$, the emission spectrum displays a single unstructured broad emission band centered at $573 \mathrm{~nm}$ (LE for Low Energy), in agreement with the yellow light observed (Figure 8a). The absolute internal quantum yield determined at room temperature is $2 \%\left(\lambda_{\mathrm{ex}}=390 \mathrm{~nm}\right)$. Emission lifetime recorded at room temperature is $\tau=2.95 \mu \mathrm{s}$. The Stokes shift calculated between excitation and emission maxima (LE) is of $8190 \mathrm{~cm}^{-1}$. 

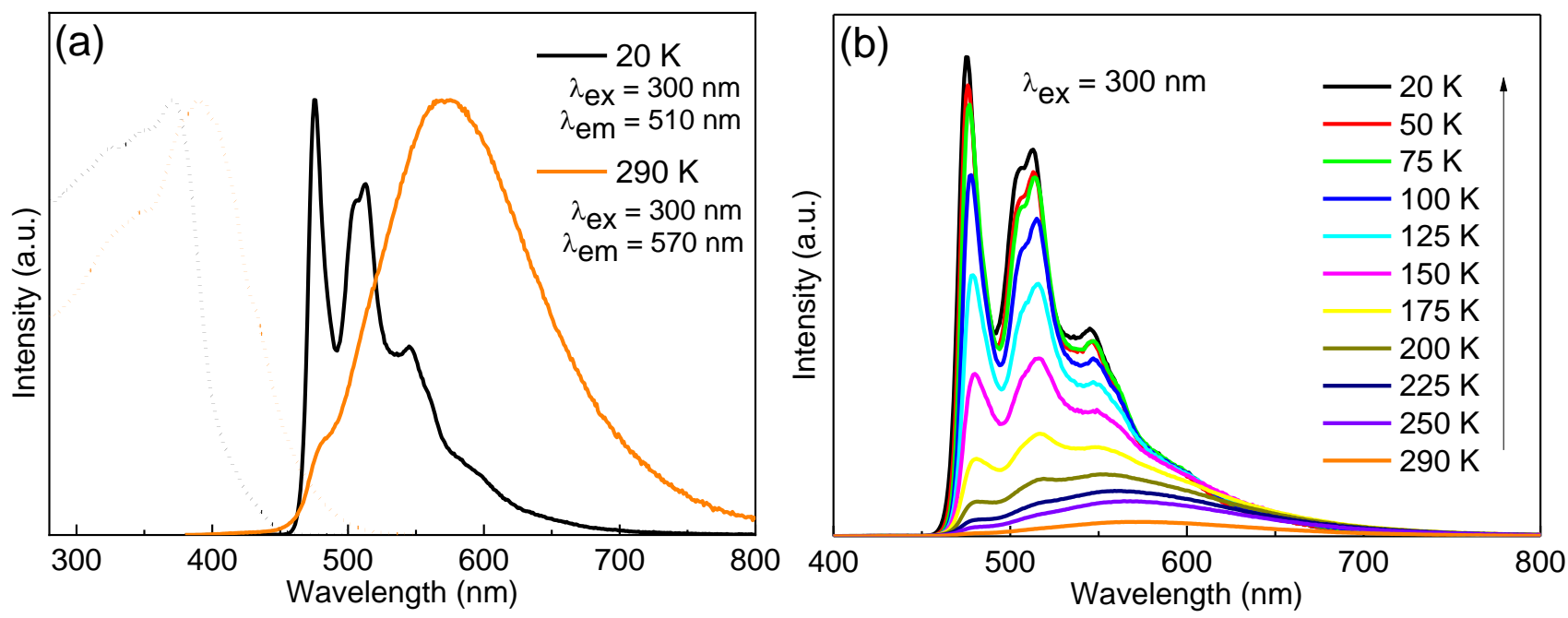

Figure 8. Temperature dependent solid-state luminescence spectra of 1. (a) Normalized emission (plain lines) and excitation spectra (dotted lines) at 20 and $290 \mathrm{~K}$. (b) Emission spectra from 20 to $290 \mathrm{~K}$ at $\lambda_{\mathrm{ex}}=300 \mathrm{~nm}$.

By lowering the temperature, another emission band at higher energy appears (HE for High Energy). This HE band is centered at $510 \mathrm{~nm}$ at $75 \mathrm{~K}$ and corresponds to the green emission observed in liquid nitrogen (Figure 7). This band presents a structured feature with three resolved peaks at 475, 510 and $545 \mathrm{~nm}$ at $20 \mathrm{~K}$ (Figure 8a). Similar excitation spectra recorded for each of these peaks confirms their same origin and their regular spacing $\left(\sim 1330 \mathrm{~cm}^{-1}\right)$ indicates their vibronic character (Figure SI). The intensity of the HE band progressively increases upon cooling with concomitant disappearance of the LE band (Figure 8b). Note that the LE band can be selectively excited. For excitation at $415 \mathrm{~nm}$, the LE band is largely predominant over the whole temperature range (Figure S5).

The broad emission band observed at room temperature can be attributed to the LE band classically observed for molecular $\left[\mathrm{Cu}_{4} \mathrm{I}_{4} \mathrm{~L}_{4}\right]$ cubane clusters. The value of $\lambda_{\max }=573 \mathrm{~nm}$ lies in the same range than that reported for $\left[\mathrm{Cu}_{4} \mathrm{I}_{4}\left(\mathrm{PPh}_{3}\right)_{4}\right](2)$ of $545 \mathrm{~nm}(\mathrm{HE}$ at $415 \mathrm{~nm})$ with a close emission lifetime value $(4.30 \mu \mathrm{s})$ but the related quantum yield value is much higher for 2 (64\%), as reported in Table S1. ${ }^{24}$ From DFT calculations, this LE band is assigned to a transition of mixed XMCT and MM character $(\mathrm{X}=\mathrm{I}$ and $\mathrm{M}=\mathrm{Cu}){ }^{24,57}$ The corresponding triplet excited stated is commonly labelled ${ }^{3} \mathrm{CC}$ for Cluster Centered. The nature of the HE band is different and implies in that case the ligands. The corresponding transition is of ${ }^{3}(\mathrm{X}, \mathrm{M}) \mathrm{LCT}$ character. The luminescence thermochromism displayed by 1 results from intensity variation of the two emission bands (HE and LE) with the temperature. This thermochromism is thus similar to that usually exhibited by molecular $\left[\mathrm{Cu}_{4} \mathrm{I}_{4} \mathrm{~L}_{4}\right]$ cubane clusters. The thermal equilibrium between the two corresponding excited states is at the origin of the intensity variation of the emission bands. At low temperature, the excited state of lowest energy is populated and is responsible for the $\mathrm{HE}$ emission. Upon increasing the temperature, thermal energy permits to populate the second excited state leading to the LE emission. The main difference with the $\left[\mathrm{Cu}_{4} \mathrm{I}_{4} \mathrm{~L}_{4}\right]$ cubane clusters, is the well resolved vibronic structuration of the $\mathrm{HE}$ band of $\mathbf{1}$. The involvement of the ligand in this transition $\left.{ }^{3}(\mathrm{X}, \mathrm{M}) \mathrm{LCT}\right)$ is in accordance with the vibronic structure which has been indeed already observed for such aromatic ligands. ${ }^{58}$ This vibrational effect can be boosted by the rigid nature of the coordination network of $\mathbf{1}$. Amongst the reported coordination polymers incorporating $\left[\mathrm{Cu}_{4} \mathrm{I}_{4}\right]$ units, only two examples exhibit luminescence thermochromism with interplay of two emission bands ${ }^{59,60}$ but in those cases, the emissions 
originate from two different copper species. Otherwise, only a shift of the single emission band is observed with temperature variation but in any case no vibronic structuration was reported. ${ }^{31,61,62,63,64}$

\section{Conclusion.}

A coordination polymer based on the polymetallic $\left[\mathrm{Cu}_{4} \mathrm{I}_{4}\right]$ center was synthesized by coordination with phenyl based-phosphine ligands. The combination of different characterization techniques permits to get insights into the polymeric structure of this compound formulated $\left[\mathrm{Cu}_{4} \mathrm{I}_{4}\left(\mathrm{Ph}_{2} \mathrm{P}\left(\mathrm{C}_{6} \mathrm{H}_{4}\right)_{2} \mathrm{PPh}_{2}\right)_{2}\right]_{\mathrm{n}}$. This coordination polymer is built on $\left[\mathrm{Cu}_{4} \mathrm{I}_{4}\right]$ centers linked by bidentate phosphine ligands forming a high dimensional structure with possible interpenetrated networks. This coordination polymer exhibits contrasted luminescence thermochromic properties ascribed to the photoactive copper iodide unit with vibronic structuration of the emission band. This study demonstrates that original photoactive coordination polymers based on copper iodide derivatives can be obtained. Such materials with additional porosity properties promises attractive potentialities for chemical sensing and detection. The rich photophysical properties and economic advantages of copper-based materials surely offer great possibilities to design readily accessible and functional light-emitting materials.

\section{Acknowledgments.}

The CNRS is thanked for funding. C. M. C. thanks the Institut Universitaire de France (IUF) for funding.

Electronic supplementary information (ESI) available: Other characterization data.

\section{References}

(1) L. E. Kreno, K. Leong, O. K. Farha, M. Allendorf, R. P. Van Duyne, J. T. Hupp, Chem. Rev. 2012, 112, 1105-1125.

(2) Z. Hu, B. J. Deibert, J. Li, Chem. Soc. Rev., 2014, 43, 5815-5840.

(3) T. Rasheed, F. Nabeel, Coord. Chem. Rev. 2019, 401, 213065.

(4) J. Hao, X. Xu, H. Fei, L. Li, B. Yan, Adv. Mater. 2018, 30, 1705634.

(5) Z.-Q. Yao, J. Xu, B. Zou, Z. Hu, K. Wang, Y.-J. Yuan, Y.-P. Chen, R. Feng, J.-B Xiong, J. Hao, X.-H. Bu, Angew. Chem. Int. Ed. 2019, 58, 5614-5618.

(6) M. D. Allendorf, C. A. Bauer, R. K. Bhaktaa, R. J. T. Houk, Chem. Soc. Rev., 2009, 38, 1330-1352.

(7) Y. Cui, Y. Yue, G. Qian, B. Chen, Chem. Rev. 2012, 112, 1126-1162.

(8) J. Rocha, L. D. Carlos, F. A. Almeida Paza, D. Ananias, Chem. Soc. Rev., 2011, 40, 926-940.

(9) Y. Fang, C. A. Sojdak, G. Dey, S. J. Teat, M. Li, M. Cotlet, K. Zhu, W. Liu, L. Wang, D. M. OCarroll, J. Li, Chem. Sci., 2019, 10, 5363-5372.

(10) W. Liu, Y. Fang, J. Li, Adv. Funct. Mater. 2018, 28, 1705593.

(11) D. M. Zink, D. Volz, T. Baumann, M. Mydlak, H. Flügge, J. Friedrichs, M. Nieger, S. Bräse, Chem. Mater. 2013, 25, 4471-4486.

(12) Z. Liu, J. Qiu, F. Wei, J. Wang, X. Liu, M. G. Helander, S. Rodney, Z. Wang, Z. Bian, Z. Lu, M. E. Thompson, C. Huang, Chem. Mater. 2014 26, 2368-2373.

(13) Z. You, H. Li, L. Zhang, B. Yu, J. Zhang, X. Wu, J. Phys. Chem. C 2017, 121, 23072-23079.

(14) Y. Yu, X.-M. Zhang, J.-P. Ma, Q.-K. Liu, P. Wang, Y.-B. Dong, Chem. Commun., 2014, 50, 1444-1446.

(15) J.-H. Wang, M. Li, D. Li, Chem. Sci. 2013, 4, 1793-1801.

(16) H. Kitagawa, H. Ohtsu, M. Kawano, Angew. Chem. Int. Ed. 2013, 52, 12395-12399.

(17) R. Peng, M. Li, D. Li, Coord. Chem. Rev. 2010, 254, 1-18.

(18) V. W.-W. Yam, V. K.-M. Au, S. Y.-L Leung, Chem. Rev. 2015, 115, 7589-7728.

(19) T.-L. Yu, Y.-M. Guo, G.-X. Wu, X.-F. Yang, M. Xue, Y.-L. Fu, M.-S. Wang, Coord. Chem. Rev. 397, 2019, 91-111. 
(20) A. Kobayashi, M. Kato, Chem. Lett. 2017, 46, 154-162.

(21) E. Cariati, E .Lucenti, C. Botta, U. Giovanella, D. Marinotto, S. Righetto, Coord. Chem. Rev. 2016, 306, 566-614.

(22) M. R. Churchill, K. L. Kalra, Inorg. Chem., 1974, 13 (8), 1899-1904.

(23) (a) H. D. Hardt, A. Pierre, Z. Anorg. Allg. Chem. 1973, 402, 107-112. (b) M. Radjaipour, D. Oelkrug, Ber. BunsenGes. Phys. Chem. 1978, 82, 159-163. (c) P. C. Ford, E. Cariati, J. Bourasssa, Chem. Rev. 1999, 99, 3625-3647. (d) T. H. Kim, Y. W. Shin, J. H. Jung, J. S. Kim, J. Kim, Angew. Chem., Int. Ed. 2008, 47, 685-688. (e) Z. Fu, J. Lin, L. Wang, C. Li, W. Yan, T. Wu, Cryst. Growth Des. 2016, 16, 2322-2327. (h) S.-Z. Zhan, M. Li, S. Ng, D. Li, Chem. Eur. J. 2013, 19, 10217-10225.

(24) S. Perruchas, C. Tard, X. F. Le Goff, A. Fargues, A. Garcia, S. Kahlal, J.-Y. Saillard, T. Gacoin, J.-P. Boilot, Inorg. Chem., 2011, 50, 10682-10692.

(25) (a) S. Perruchas, X. F. Le Goff, S. Maron, I. Maurin, F. Guillen, A. Garcia, T. Gacoin, J.-P. Boilot, J. Am. Chem. Soc. 2010, 132, 10967-10969. (b) X.-C. Shan, F.-L Jiang, H.-B. Zhang,.X.-Y. Qian, L. Chen, M.-Y. Wu, S. A. Al-Thabaiti, M.C. Hong, Chem. Commun. 2013, 49, 10227-10229. (c) X.-C. Shan, F.-L. Jiang, L. Chen, M.-Y. Wu, J. Pan, X.-Y. Wan, M.C. Hong, J. Mater. Chem. C, 2013, 4339-4349. (d) Q. Benito, X. F. Le Goff, S. Maron, A. Fargues, A. Garcia, C. Martineau, F. Taulelle, S. Kahlal, T. Gacoin, J.-P. Boilot, S. Perruchas, J. Am. Chem. Soc., 2014, 136, 11311-11320. (e) B. Huitorel, H. El Moll, M. Cordier, A. Fargues, A. Garcia, F. Massuyeau, C. Martineau-Corcos, T. Gacoin, S. Perruchas, Inorg. Chem. 2017, 56, 12379-12388. (f) B. Huitorel, Q. Benito, A. Fargues, A. Garcia, T. Gacoin, J.-P. Boilot, S. Perruchas, F. Camerel, Chem. Mater. 2016 28, 8190-8200. (g) B. Huitorel, R. Utrera-Melero, F. Massuyeau, J.-Y. Mevelec, B. Baptiste, A. Polian, T. Gacoin, C. Martineau-Corcos, S. Perruchas, Dalton Trans. 2019, 48, 7899-7909.

(26) (a) D. Tran, J. L. Bourassa, P. C. Ford, Inorg. Chem. 1997, 36, 439-442. (b) A. Vogler, H. Kunkely, J. Am. Chem. Soc. 1986, 108, 7211-7212. (c) I. Roppolo, E. Celasco, M. Sangermano, A. Garcia, T. Gacoin, J.-P. Boilot, S. Perruchas, J. Mater. Chem. C, 2013, 1 (36), 5725-5732.

(27) (a) C.- W. Zhao, J.-P. Ma, Q.-K. Liu, X.-R. Wang, Y. Liu, J. Yang, J.-S. Yang, Y. B. Dong, Chem. Commun., 2016, 52, 5238-5241. (b) S. Cho, Y. Jeon, S. Lee, J. Kim, T. H. Kim, Chem. - Eur. J. 2015, 21, 1439-1443. (c) H. Park, E. Kwon, H. Chiang, H. Im, K. Yeol Lee, J. Kim, T. H. Kim, Inorg. Chem. 2017, 56, 8287-8294. (d) J. P. Killarney, M. McKinnon, C. Murphy, K. M. Henline, C. Wang, R. D. Pike, H. H. Patterson, Inorg. Chem. Comm. 2014, 40, 18-21.

(28) C. Chen, R.-H. Li, B.-S. Zhu, K.-H. Wang, J.-S. Yao, Y.-C. Yin, M.-M. Yao, H.-B. Yao, S.-H. Yu, Angew. Chem. Int. Ed. 2018, 57, 7106-7110.

(29) Y. Fang, W. Liu, S. J. Teat, G. Dey, Z. Shen, L. An, D. Yu, L. Wang, M. O’Carroll, J. Li, Adv. Funct. Mater. 2017, 27, 1603444.

(30) M. Xie, C. Han, J. Zhang, G. Xie, H. Xu, Chem. Mater. 2017, 29, 6606-6610.

(31) See for examples: (a) J. P. Safko, J. E. Kuperstock, S. M. Mccullough, A. M. Noviello, X. Li, J. P. Killarney, C. Murphy, H. H. Patterson, A. Bayse, R. D. Pike, Dalton Trans., 2012, 41, 11663. (b) X. Chai, S. Zhang, Y. Chen, Y. Sun, H. Zhang, X. Xu, Inorg. Chem. Commun. 2010, 13, 240. (c) C.-W. Zhao, J.-P. Ma, Q.-K. Liu, X.-R. Wang, Y. Liu, J. Yang, J.S. Yang, Y.-B. Dong, Chem. Commun., 2016, 52, 5238-5241. (d) M. Yu, C. Liu, S. Li, Y. Zhao, J. Lv, Z. Zhuo, F. Jiang, L. Chen, Y. Yu, M. Hong, Chem. Commun., 2020, 56, 7233-7236.

(32) See for examples: (a) J. Y. Lee, S. Y. Lee, W. Sim, K. Park, J. Kim, S. S. Lee, J. Am. Chem. Soc., 2008, 130, 6902. (b) A. Schlachter, A. Lapprand, D. Fortin, C. Strohmann, P. D. Harvey, M. Knorr, Inorg. Chem. 2020, 59, 3686-3708.

(33) Y. Kang, F. Wang, J. Zhang, X. Bu, J. Am. Chem. Soc. 2012, 134, 17881-17884.

(34) X. Luo, Y. Cao, T. Wang, G. Li, J. Li, Y. Yang, Z. Xu, J. Zhang, Q. Huo, Y. Liu, M. Eddaoudi, J. Am. Chem. Soc. 2016, 138, 786-789.

(35) S. Hu, M. L. Tong, Dalton Trans. 2005, 1165-1167.

(36) X. X. Li, Y. X. Wang, R. H. Wang, C. Y. Cui, C. B. Tian, G. Y. Yang, Angew. Chem. Int. Ed. 2016, 55, 6462-6466.

(37) Y. X. Tan, Y. P. He, J. Zhang, Chem. Mater. 2012, 24, 4711-4716.

(38) L.-D. Lin, D. Zhao, X.-X. Li, S.-T. Zheng, Chem. Eur. J. 2019, 25, 442-453.

(39) S. L. James, Chem. Soc. Rev. 2009, 38, 1744-1758.

(40) M. M. Siddiqui, J. T. Mague, M. S. Balakrishna, Inorg. Chem. 2015, 54, 6063-6065.

(41) I. O. Koshevoy, P. V Ostrova, A. J. Karttunen, A. S. Melnikov, M. a Khodorkovskiy, M. Haukka, J. Jänis, S. P. Tunik, T. a Pakkanen, Dalton Trans., 2010, 39, 9022. 
(42) D. Massiot, F. Fayon, M. Capron, I. King, S. Le Calvé, B. Alonso, J. O. Durand, B. Bujoli, Z. Gan, G. Hoatson, Magn. Reson. Chem., 2002, 40, 70.

(43) A. Boultif , D. Louer, J. Appl. Cryst. 2004, 37, 724-731.

(44) J. Rodriguez-Carvajal, Physica B. 1993, 192, 55.

(45) T. Roisnel, J. Rodriguez-Carvajal, Proceedings of the Seventh European Powder Diffraction Conference (EPDIC 7),

Ed. R. Delhez and E.J. Mittenmeijer, 2000, 118-123.

(46) H. Kitagawa, Y. Ozawa, K. Toriumi, Chem. Commun. 2010, 46, 6302-6304.

(47) L. Maini, D. Braga, P. P. Mazzeo, B. Ventura, Dalton Trans., 2012, 41, 531-539.

(48) B. Huitorel, R. Utrera-Melero, F. Massuyeau, J.-Y. Mevelec, B. Baptiste, A. Polian, T. Gacoin, C. Martineau-Corcos, S. Perruchas, Dalton Trans. 2019, 48, 7899-7909.

(49) Q. Benito, X. Le Goff, G. Nocton, A. Fargues, A. Garcia, A. Berhault, S. Kahlal, J.-Y. Saillard C. Martineau, J. Trebosc T. Gacoin, J.-P. Boilot, S. Perruchas, Inorg. Chem. 2015, 54, 4483-4494.

(50) Q. Benito, I. Maurin, M. Poggi, C. Martineau-Corcos, T. Gacoin, J.-P Boilot, S. Perruchas, J. Mater. Chem. C, 2016, 4, 11231-11237.

(51) J. A. Tang, B. D. Ellis, T. H. Warren, J. V. Hanna, C. L. B. Macdonald, R. W. Schurko, J. Am. Chem. Soc. 2007, 129, 13049-13065.

(52) G. Mouchaham, L. Cooper, N. Guillou, C. Martineau, E. Elkaïm, S. Bourrelly, P. L. Llewellyn, C. Allain, G. Clavier, C. Serre, T. Devic, Angew. Chem. Int. Ed. 2015, 54, 13297.

(53) P. Bartos, P. Taborsky, M. Necas, Phosphorus, Sulfur, and Silicon and the Related Elements, 2016, 191, 645.

(54) G. A. Bowmaker, P. C. Healy, Spectrochimica Acta Part A: Molecular Spectroscopy 1988, 44, 115-119.

(55) G. A. Bowmaker, R. J. Knappstein, S. F. Tham, Aust. J. Chem., 1978, 31, 2137-2143.

(56) S. Attar, G. A. Bowmaker, N. W. A1cock, J. S. Frye, W. H. Bearden, J. H. Nelson, Inorg. Chem. 1991, 30, 4143-4153.

(57) (a) M. Vitale, C. K. Ryu, W. E. Palke, P. C. Ford, Inorg. Chem. 1994, 33, 561. (b) F. De Angelis, S. Fantacci, A. Sgamellotti, E. Cariati, R. Ugo, P. C. Ford, Inorg. Chem. 2006, 45, 10576. (c) A. Vega, J.-Y. Saillard, Inorg. Chem. 2004, $43,4012$.

(58) I. O. Koshevoy, E. S. Smirnova, M. Haukka, A. Laguna, J. Camara Chueca, T. A. Pakkanen, S. P. Tunik, I. Ospino, Olga Crespo, Dalton Trans., 2011, 40, 7412-7422.

(59) S.-Z. Zhan, M. Li, X.-P. Zhou, J.-H. Wang, J.-R. Yan, D. Li, Chem. Commun., 2011, 47, 12405.

(60) X. Shan, F. Jiang, D. Yuan, H. Zhang, M. Wu, L. Chen, J. Wei, S. Zhang, J. Panab, M. Hong, Chem. Sci., 2013, 4, 1484.

(61) D. Braga, L. Maini, P. P. Mazzeo, B. Ventura, Chem. Eur. J., 2010, 16, 1553.

(62) D. Sun, S. Yuan, H. Wang, H.-F. Lu, S.-Y. Feng, D.-F. Sun, Chem. Commun., 2013, 49, 6152.

(63) A. Raghuvanshi, C. Strohmann, J.-B. Tissot, S. Clément, A. Mehdi, S. Richeter, L. Viau, M. Knorr, Chem. Eur. J. 2017, 23, 16479-16483.

(64) L.-D. Lin, Z. Li, J.-H. Liu, Y.-Q. Sun, X.-X. Li, S.-T. Zheng, Chem. Commun., 2019, 55, 1511-15116. 